\title{
Correction to: Teacher Questioning Practices in Early Childhood Science Activities
}

\author{
Erin Hamel ${ }^{1}$ [ $\cdot$ Yuenjung $\mathrm{Joo}^{1} \cdot$ Soo-Young Hong ${ }^{1} \cdot$ Anna Burton $^{2}$
}

Published online: 13 August 2020

(c) Springer Nature B.V. 2020

\section{Correction to: Early Childhood Education Journal https://doi.org/10.1007/s10643-020-01075-z}

The original version of the article unfortunately contained an error. The following funding information was missed to Publisher's Note Springer Nature remains neutral with regard to include in the article.

Funding This project was funded by the University of Nebraska-Lincoln and the Fundação Maria Cecilia Souto Vidigal (Foundation) through its collaborative Pilot Impact Program (PI: Soo-Young Hong, Ph.D.). Opinions expressed herein are those of the authors and do not reflect the position of the University of Nebraska or Foundation.

The original article can be found online at https://doi.org/10.1007/ s10643-020-01075-z.

Erin Hamel

erin.hamel@huskers.unl.edu

1 University of Nebraska-Lincoln, Lincoln, NE, USA

2 University of Texas McGovern Medical School Children's Learning Institute, Houston, TX, USA 